\title{
ISOLATION AND SEQUENCING OF MYCOPLASMA ARGININI GENOME ASSOCIATED WITH RESPIRATORY DISORDER IN SMALL RUMINANTS
}

\author{
ELSHAFAY, DINA ${ }^{1}$; NERMIN AWAD ${ }^{2}$; ELNAKER F. YASSER ${ }^{3}$ and YOUNIS E. EMAD ${ }^{4}$ \\ ${ }^{1}$ Mycoplasma Department, Animal Health Research Institute, Dokii, Giza. \\ ${ }^{2}$ Bacteriology, Mycology and Immunology, Faculty of Veterinary Medicine, Mansoura University. \\ ${ }^{3}$ Department of Animal Medicine, Fac. Vet. Med. New Valley, Assiut University. \\ ${ }^{4}$ Department of Internal Medicine and Infectious Diseases, Fac. Vet. Med, Mansoura Univ.
}

Received: 31 December 2017; $\quad$ Accepted: 31 January 2018

\begin{abstract}
The purpose of this study was to evaluate the role and variety of Mycoplasma arginini (M. arginini) in respiratory manifestation in sheep and goat flocks. M. arginine, were isolated from 40 nasal swabs out of 160 nasal swabs examined which obtained from (79) sheep and (81) goat with respiratory manifestations. In sheep, the percent of isolation was $(25.32 \%), 20$ isolate out of 79 nasal swabs, while the percent of isolation in goat was (24.69\%) 20 isolate out of 81 nasal swabs examined. Higher percent of isolation was found in age group (1-2) year old sheep (50\%) as 7 isolates out of 14 nasal swabs examined, while in goat the higher percent of isolation was in age group less than one year by $44 \%$ (11 isolates out of 25 nasal swabs examined. The lower isolation rates were found in adult sheep and goat ( 3 - 4 years old) by $15.38 \%$ in sheep and $6.45 \%$ in goat. Mycoplasma isolates was molecularly characterized by PCR and DNA sequencing as M. arginini and submitted to Gen Bank. An accession number has been assigned to each nucleotide sequence and was KP972458-KP972459.
\end{abstract}

Key words: Goat - Mycoplasma - PCR - sheep pneumonia.

\section{INTRODUCTION}

Respiratory diseases can cause prolonged illness or even sudden death in sheep and goat. Pneumonia appear in all ages of sheep, which not only has a direct effect on their growth but also plays important role in lamb mortality (Thonney et al., 2008), more over contagious caprine pleuropneumonia (CCPP) from the pneumonic diseases which exaggerate economic losses due to the risk of death in goat flocks (Ruragirwa and McGuire, 2003). Many infecting agent incriminated, it may be bacteria, Chlamydia, Mycoplasma, or viruses. Pasteurellosis or mannheimiosis, the most predominant causes especially in sheep while Mycoplasma pneumonia is often unnoticed. Other bacteria infrequently present with respiratory disease in small ruminants are Arcanobacterium pyogenes, Staphylococcus spp., $\quad$ Streptococcus spp., Haemophilus spp., and Klebsiella pneumonia (Nicholas et al., 2008a).

Although $M$. arginini in sheep and goat is an important pathogen by itself but co infection by $\mathrm{M}$. haemolytica exaggerates the pathologic injury of

Corresponding author: Dr. ELNAKER F. YASSER

E-mail address: yasserelnaker@yahoo.com

Present address: Department of Animal Medicine, Fac. Vet. Med. New Valley, Assiut University pneumonia (Lin et al., 2008; Nicholas et al., 2008b). Mycoplasma arginini is frequently present in lungs, mouth, and esophagus of pneumonic sheep (Cottew, 1979), and (Ayşe Kılic et al., 2013), Also M. arginini isolated from cases of ovine keratoconjunctivitis. (Leach, 1970).

M. arginini is a mammalian parasite, which found in many animal species. Accumulating signs in the case reports suggests the pathogenic role of M. arginini as a new human zoonosis. (Yechouron et al., 1992). Therefore the aim of this work is to investigate more about the role of $M$. arginini in the respiratory affections in sheep and goat beside the phylogenic analysis of native strains.

\section{MATERIALS AND METHODS}

\section{1- Animals}

This study was performed in winter months on four flocks of sheep and goats containing 712 sheep and 305 goats in Sherbin and Dikrins cities, follows the governorate of Dakahlia, Egypt. These animals were classified according to their ages into 3 groups (Table 3 ), the flocks examined clinically according to Kelly (1990) for respiratory manifestation, and data and type of housing of examined animals were recorded. 


\section{2- Samples}

One hundred and sixty nasal swabs were collected on PPLO broth from sheep and goats with signs of respiratory manifestation. The swabs were preserved at $-20^{\circ} \mathrm{c}$ until used.

\section{3- Isolation of Mycoplasma:}

a) Media used for cultivation and isolation of Mycoplasma:

a.1) Liquid and solid media prepared as described by Sabry and Ahmed (1975). a.2) Digitonin sensitivity test was done for the obtained isolates according to Erno and Stipkovits (1973).

a.3) Biochemical characterization was carried out by glucose fermentation and arginine deamination tests as described by Erno and Stipkovits (1973). Film and spot formation medium (Fabricant and Freundt, 1967).

\section{4 - Polymerase chain reaction (PCR):}

A- Preparation of samples for DNA extraction (Yleana et al., 1995).

B- Primer selection.

Table 1: Primers of Mycoplasma as shown in table below.

\begin{tabular}{|c|c|c|c|c|c|}
\hline $\begin{array}{l}\text { Mycoplasma } \\
\text { Species }\end{array}$ & $\begin{array}{l}\text { Forwarded } \\
\text { primer }\end{array}$ & Reverse primer & $\begin{array}{l}\text { product } \\
\text { size (bp) }\end{array}$ & Thermal cycle & Reference \\
\hline $\begin{array}{l}\text { Sequence of } 16 \mathrm{~S} \\
\text { common gene } \\
\text { for ruminant } \\
\text { Mycoplasma }\end{array}$ & $\begin{array}{l}\text { MunivF 5- AGA } \\
\text { TC CTA CGG } \\
\text { GAG CA GCA -3 }\end{array}$ & $\begin{array}{c}\text { MunivR 5' ACT } \\
\text { GC GAT TCC } \\
\text { GAC TTC ATG 3', }\end{array}$ & 1000 & $\begin{array}{l}\text { Initial denaturation step at } 94{ }^{\circ} \mathrm{C} \text { for } 5 \\
\text { min., followed by } 35 \text { cycles of } \\
\text { denaturation at } 94{ }^{\circ} \mathrm{C} \text { for } 1 \text { min, } \\
\text { annealing at } 55^{\circ} \mathrm{C} \text { for } 1 \text { min., and } \\
\text { extension at } 72^{\circ} \mathrm{C} \text { for } 1.5 \mathrm{~min} \text {. A final } \\
\text { extention step at } 72^{\circ} \mathrm{C} \text { for } 10 \mathrm{~min}\end{array}$ & $\begin{array}{l}\text { Alberto et } \\
\text { al. (2006) }\end{array}$ \\
\hline $\begin{array}{l}\text { Mycoplasma } \\
\text { mycoides } \\
\text { Subspecies capri }\end{array}$ & $\begin{array}{l}5- \\
\text { ACTGAGCAATT } \\
\text { CCTCTT-3 }\end{array}$ & $\begin{array}{l}5- \\
\text { TTAATAAGTCTC } \\
\text { TATATGAAT-3 }\end{array}$ & 195 & $\begin{array}{l}\text { Initial denaturation } 94{ }^{\circ} \mathrm{C} \text { for } 5 \mathrm{~min} \text {, } \\
\text { Then } 35 \text { cycles of Denaturation } 94{ }^{\circ} \mathrm{C} \\
\text { for } 1 \mathrm{~min}, \text { Annealing } 46{ }^{\circ} \mathrm{C} \text { for } 90 \mathrm{sec} \text {, } \\
\text { Extension } 72{ }^{\circ} \mathrm{C} \text { for } 1 \mathrm{~min} \text {, final } \\
\text { Extension } 94{ }^{\circ} \mathrm{C} \text { for } 10 \mathrm{~min} .\end{array}$ & $\begin{array}{l}\text { Vijay et al. } \\
\text { (2013) }\end{array}$ \\
\hline $\begin{array}{c}\text { Mycoplasma } \\
\text { agalactiae }\end{array}$ & $\begin{array}{l}\text { MAGAUVRC1-L } \\
\text { 5' - CTC AAA } \\
\text { AAT ACA TCA } \\
\text { ACA AGC - 3' }\end{array}$ & $\begin{array}{l}\text { MAGAUVRC1-R } \\
\text { 5' - CTT CAA } \\
\text { CTG ATG CAT } \\
\text { CAT AA - 3' }\end{array}$ & 1624 & $\begin{array}{l}\text { initial sample denaturation, } 5 \mathrm{~min} \text { at } \\
95^{\circ} \mathrm{C} 35 \text { cycles: denaturation, } 30 \mathrm{~s} \text { at } \\
94{ }^{\circ} \mathrm{C} \text {; annealing, } 30 \mathrm{~s} \text { at } 50{ }^{\circ} \mathrm{C} \text {; } \\
\text { extension, } 1 \text { min at } 72^{\circ} \mathrm{C} \\
\text { - completion of the amplification } \\
\text { process by final extension at } 72{ }^{\circ} \mathrm{C} \text { for } \\
10 \text { min }\end{array}$ & $\begin{array}{l}\text { Zendulkova } \\
\text { et al. (2007) }\end{array}$ \\
\hline $\begin{array}{l}\text { Mycoplasma } \\
\text { ovipneumoniae } \\
\text { (16S-23S } \\
\text { intergenic } \\
\text { spacer) }\end{array}$ & $\begin{array}{l}\text { MoIGSF } \\
\text { GGAACACCTCC } \\
\text { TTTCTACGG }\end{array}$ & $\begin{array}{c}\text { MoIGSR } \\
\text { CCAAGGCATCC } \\
\text { ACCAAATAC }\end{array}$ & 390 & $\begin{array}{l}\text { initial denaturation step at } 95^{\circ} \mathrm{C}(15 \\
\text { min) } 30 \text { cycles at } 95^{\circ} \mathrm{C} \text { for } 30 \mathrm{~s} \text {, at } \\
58^{\circ} \mathrm{C} \text { for } 30 \mathrm{~s} \text {, and at } 72^{\circ} \mathrm{C} \text { for } 30 \text { final } \\
\text { extension step at } 72^{\circ} \mathrm{C}(5 \mathrm{~min})\end{array}$ & $\begin{array}{l}\text { Thomas et } \\
\text { al. (2012) }\end{array}$ \\
\hline
\end{tabular}

PCR amplification for Mycoplasma was performed in $50 \mu \mathrm{l}$ reaction mixture consisting of $5 \mu \mathrm{l}$ of $50 \mathrm{ng}$ Mycoplasma genomic DNA, $25 \mu 1$ of 2 x Master mix (Multiplex gen) VIVANTIS , $1 \mu$ l of 50 pmol of each primer, $0.5 \mathrm{mM} \mathrm{MgCl}$, and $35 \mu \mathrm{l}$ of DNase- RNasefree deionized water. DNA amplification was performed as shown in Table (2), Following amplification, $5 \mu \mathrm{l}$ of each amplicon was mixed with sample buffer and applied on agarose gel $1 \%$ (w/v) containing $0.5 \mu \mathrm{g}$ of ethidium bromide. The samples were electrophoresed at 50 volts for $20 \mathrm{~min}$ on a horizontal electrophoresis unit. A 100 bp DNA ladder was used as molecular weight standard (VIVANTIS). After electrophoresis, the gel was visualized photographed.
5- Selected published sequences of $16 \mathrm{~S}$ rRNA genes, which used in sequence analysis and phylogeny:

>M.arginini.ATCC23243 gb|JN935883.1|:319-1256

>M.arginini.D7 gb|HQ661822.1|:269-1206

>M.arginini.E3.5 gb|HQ661820.1|:269-1206

>M.arginini.787 gb|HQ661826.1|:269-1207

>M.arginini.HAZ145_1 dbj|AP014657.1|:140970-

141907

>M.arginini.C2-Ass-11 gb|JN543264.1|:1-932

>M.arginini.E2.5 gb|HQ661827.1|:350-1287

>M.arginini.C1-Beh-10 gb|HM635904.1|:1-932

>M.phocicerebrale.1049 gb|JN935885.1|:320-1257

$>$ M.auris.UIA ref|NR_026035.1|

$>$ M.neophronis.G.A ref|NR_108494.1|

>M.cloacale.383 ref|NR_024985.1|:308-1244

>M.salivarium.PG20 ref|NR_041745.1|:310-1247

>M.hyosynoviae.S-16 ref|NR_029183.1|:341-1277 


\section{6- Sequence and phylogenetic analysis:-}

Sequencing of the PCR products of 16S rRNA gene were done in both directions then 943 bp sequences was used for nucleotide analysis. The original sequence was trimmed to remove unclear nucleotide sequences that appear usually in the beginning of the sequencing reaction. The nucleotide sequences of the M. arginini were compared with others published on Gen Bank using BLAST 2.1 and PSI- BLAST search programs, (National Center for Biotechnology Information "NCBI" http:// www.ncbi.nlm.nih.gov/). The obtained nucleotide sequences comparisons and their multiple alignments with reference $M$. arginini and other Mycoplasmas sequences were done using the BioEdit sequence alignment editor, (Hall, 1999) and MegAlign ${ }^{\mathrm{TM}}$ (DNASTAR, Lasergene ${ }^{\circledR}$, and Version 7.1.0, USA). The phylogenetic trees were raised using MegAlign ${ }^{\mathrm{TM}}$ for tree reconstruction of sequences by Neighbor-joining method based on Crustal. Random seeding value of 111 was used for
Bootstrapping values calculation. (Thompson $\underline{e t} \underline{a l}$., 1994) For end gaps Clustal V was used. Sequence divergence and identity percent's were calculated by MegAlign ${ }^{\mathrm{TM}}$. The obtained sequences were submitted to Gen Bank (after trimming and correction) and retrieved accession numbers; KP972458 and KP972459 for samples sequences which designated Dak-1/M.arg/EG014 and Dak-2/M.arg/EG014 respectively.

\section{RESULTS}

\section{Clinical examination}

Percent of respiratory manifestations in examined 4 flocks were $11.1 \%(79 / 712)$ and $26.56 \%(81 / 305)$ in sheep and goats respectively, the clinical manifestations varies from nasal discharge, cough to dyspnea. (Table 2 and fig 1,2).

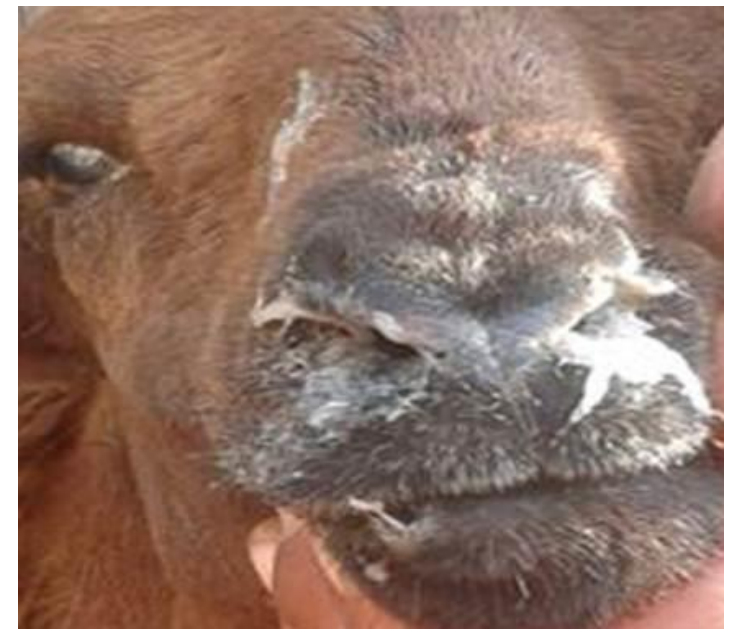

Fig. (1): Sheep with nasal discharge

Table 2: Percent of sheep clinically affected with respiratory manifestations.

\begin{tabular}{|c|c|c|c|c|c|c|}
\hline Flock No. & Sheep & $\begin{array}{l}\text { Clinically } \\
\text { affected }\end{array}$ & $\%$ & Goat & $\begin{array}{l}\text { Clinically } \\
\text { affected }\end{array}$ & $\%$ \\
\hline Flock 1 & 170 & 17 & 10 & 55 & 20 & 36.36 \\
\hline Flock 2 & 184 & 16 & 8.7 & 90 & 26 & 28.88 \\
\hline Flock 3 & 150 & 22 & 14.67 & 82 & 19 & 23.17 \\
\hline Flock 4 & 208 & 24 & 11.54 & 78 & 16 & 20.51 \\
\hline Total & 712 & 79 & 11.1 & 305 & 81 & 26.56 \\
\hline
\end{tabular}




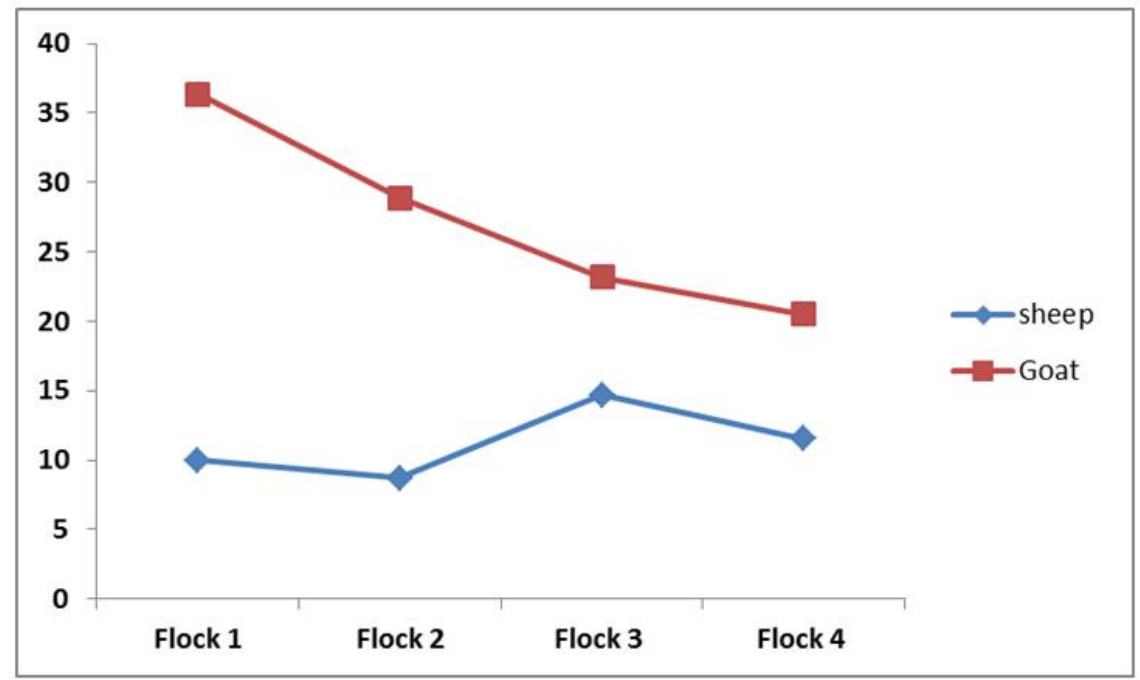

Fig. (2): Percent of clinically affected sheep with respiratory manifestations.

Isolation of Mycoplasma spp.

Table 3: Mycoplasma isolation from nasal swabs of sheep and goat with respiratory manifestation in relation to age and species of the animals.

\begin{tabular}{ccccccc}
\hline Species / Age & \multicolumn{3}{c}{ Sheep } & \multicolumn{2}{c}{ Goat } \\
\cline { 2 - 7 } & Total & +ve & $\boldsymbol{\%}$ & Total & +ve & \% \\
\hline < 1 year & 39 & 9 & 23.07 & 25 & 11 & 44 \\
\hline $\mathbf{1}$ - 2 year & 14 & 7 & 50 & 25 & 7 & 28 \\
\hline 3 - 4 year & 26 & 4 & 15.38 & 31 & 2 & 6.45 \\
\hline Total & $\mathbf{7 9}$ & $\mathbf{2 0}$ & $\mathbf{2 5 . 3 2}$ & $\mathbf{8 1}$ & $\mathbf{2 0}$ & $\mathbf{2 4 . 6 9}$ \\
\hline
\end{tabular}

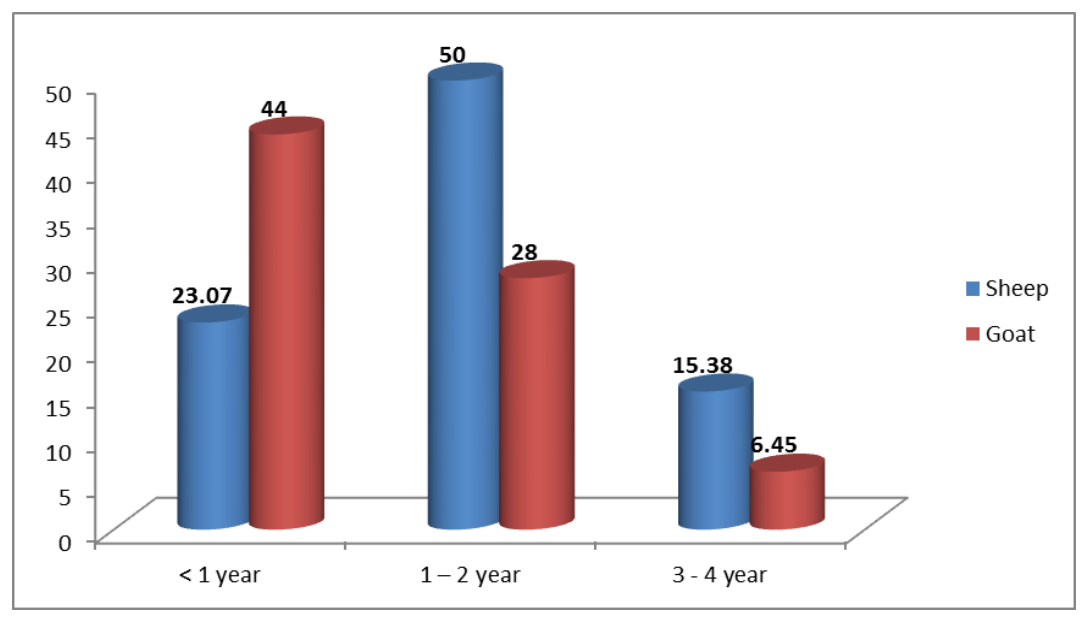

Fig. (3): Mycoplasma isolation from nasal swabs of sheep and goat with respiratory manifestation in relation to age and species of the animals

In Table (3) \& Fig (3), percent of isolation of Mycoplasma from examined nasal swabs were $25.32 \%(20 / 79)$ and $24.69 \%(20 / 81)$ in sheep and goat respectively.

According to age, the higher percent of isolation was found in age group (1-2) year old sheep (50\%) as 7 isolates from examined 14 nasal swab were recorded, while in goat the higher percent of isolation were in age group less than one year old by $44 \%$ (11 isolates from examined 25 nasal swab). The lower isolation rate was found in adult sheep and goat (3-4year-old) by $15.38 \%$ and $6.45 \%$ respectively. 


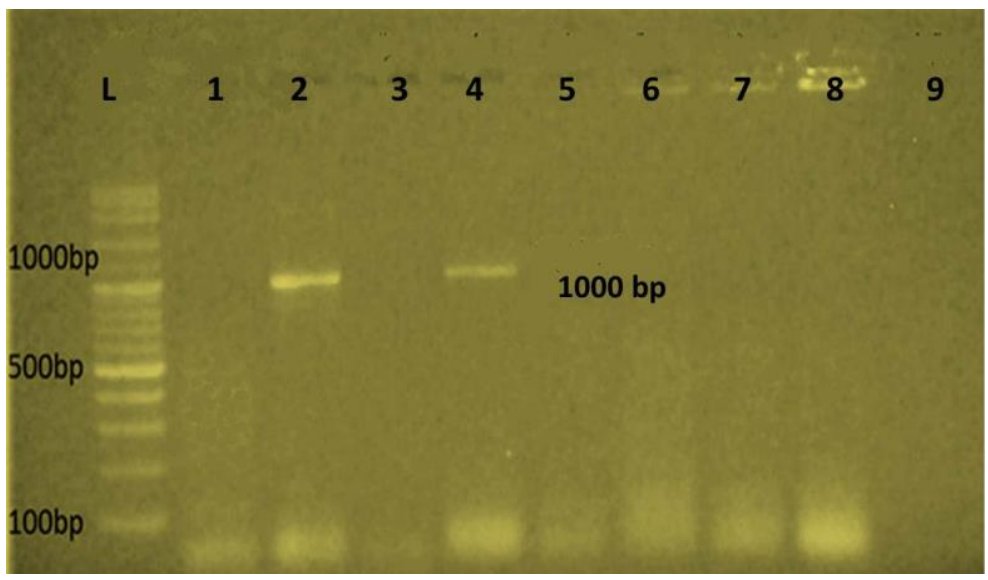

\section{Polymerase chain reaction (PCR).}

Fig (4): Gel electrophoresis of PCR products of Mycoplasma 16s rRNA gene. L: VC100BP Puls DNA Ladder, Lane 2 and 4: The amplified products prepared from colony of positive nasal swabs of diseased sheep, Lane 1: negative control, Lanes 3 \& 5-9 negative samples.

PCR results of the 40 isolates were found positive with genus-specific primers, 20 isolate from sheep and 20 isolates from goat were positive with speciesspecific primers for Mycoplasma. arginini. The bands obtained were 1000 bp with the Mycoplasma genus specific primer (Fig. 4).

In this study according to phylogenetic relatedness, the isolates classified into two unlike groups. Among the members of these two groups there were no changes in the nucleotide sequences of the 16s RNA gene. Phylogenetic distances among the strains are shown in Table (4) Figure (5). Among the isolates, two showed identical nucleotide sequence, meaning they represent the same strains. Isolates KP972458 and KP972459 for samples sequences, which designated Dak-1/M.arg/EG014 and Dak-2/M.arg/ EG014 respectively.

Table 4: The percentages of identities and diversities of nucleotide sequences of the Mycoplasma arginini 16s rRNA in the present study.

\begin{tabular}{|c|c|c|c|c|c|c|c|c|c|c|c|c|c|c|c|c|c|c|}
\hline \multicolumn{19}{|c|}{ Percent Identity } \\
\hline \multirow{17}{*}{$\begin{array}{l}8 \\
8 \\
8 \\
8 \\
8\end{array}$} & 1 & 2 & 3 & 4 & 5 & 6 & 7 & 8 & 9 & 10 & 11 & 12 & 13 & 14 & 15 & 16 & & \\
\hline & & 98.6 & 99.4 & 80.4 & 99.4 & 99.4 & 89.1 & 99.4 & 88.8 & 89.0 & 98.3 & 98.1 & 86.8 & 96.7 & 98.4 & 86.2 & 1 & Dak_1-M.arg-EG014 \\
\hline & 1.4 & & 88.8 & 88.8 & 98.8 & 88.8 & 88.7 & 98.9 & 98.5 & 88.8 & 97.8 & 97.6 & 96.3 & 96.2 & 85.0 & 85.7 & 2 & Dak_2-M.arg-EG014 \\
\hline & 0.8 & 1.1 & & 100.0 & 100.0 & 100.0 & 98.8 & 100.0 & 99.6 & 80.5 & 88.8 & 88.7 & 97.4 & 87.3 & 97.0 & 80.8 & 3 & M.argininiATCC23243 \\
\hline & 0.8 & 1.1 & 0.0 & & 100.0 & 100.0 & 82.8 & 100.0 & 98.6 & 80.5 & 88.8 & 98.7 & 97.4 & 97.3 & 87.0 & 86.8 & 4 & M.arginini.D7 \\
\hline & 0.8 & 1.1 & 0.0 & 0.0 & & 100.0 & 98.8 & 100.0 & 99.6 & 98.5 & 88.8 & 88.7 & 97.4 & 97.3 & 97.0 & 96.8 & 5 & M.arginini.E3.5 \\
\hline & 0.8 & 1.1 & 0.0 & 0.0 & 0.0 & & 89.8 & 100.0 & 99.8 & 89.5 & 98.8 & 98.7 & 97.4 & 97.3 & 97.0 & 96.8 & 6 & M.arginini.787 \\
\hline & 0.8 & 1.3 & 0.2 & 0.2 & 0.2 & 0.2 & & 90.8 & 89.4 & 99.2 & 88.7 & 98.5 & 97.2 & 87.1 & 86.8 & 80.7 & 7 & M.arginini.HAZ145_1 \\
\hline & 0.6 & 1.1 & 0.0 & 0.0 & 0.0 & 0.0 & 0.2 & & 99.6 & 89.5 & 88.9 & 88.7 & 97.4 & 97.3 & 97.0 & 96.8 & 8 & M.arginini.C2-Ass-11 \\
\hline & 1.1 & 1.5 & 0.4 & 0.4 & 0.4 & 0.4 & 0.8 & 0.4 & & 99.0 & 88.5 & 98.3 & 97.0 & 86.8 & 86.6 & 88.4 & 9 & M.arginini.E2.5 \\
\hline & 1.0 & 1.1 & 0.5 & 0.5 & 0.5 & 0.5 & 0.8 & 0.5 & 1.0 & & 98.4 & 88.2 & 96.9 & 96.8 & 86.7 & 86.5 & 10 & M.arginini.C1-Beh-10 \\
\hline & 1.7 & 2.2 & 1.1 & 1.1 & 1.1 & 1.1 & 1.3 & 1.1 & 1.5 & 1.6 & & 88.7 & 97.7 & 97.3 & 86.8 & 80.7 & 11 & M.phocicerebrale.1048 \\
\hline & 1.8 & 2.4 & 1.3 & 1.3 & 1.3 & 1.3 & 1.5 & 1.3 & 1.7 & 1.8 & 1.3 & & 97.2 & 87.2 & 96.8 & 86.8 & 12 & M.aunis.UIA \\
\hline & 3.3 & 3.8 & 2.8 & 2.6 & 2.6 & 2.6 & 2.8 & 2.6 & 3.1 & 3.2 & 2.4 & 2.8 & & 97.3 & 86.2 & 96.4 & 13 & M.neophronis.G.A \\
\hline & 3.4 & 3.8 & 2.7 & 2.7 & 27 & 2.7 & 2.8 & 27 & 3.2 & 3.3 & 2.7 & 2.8 & 2.7 & & 98.1 & 85.8 & 14 & M.cloacale. 383 \\
\hline & 3.7 & 4.3 & 3.1 & 3.1 & 3.1 & 3.1 & 3.3 & 3.1 & 3.5 & 3.4 & 3.3 & 3.2 & 4.0 & 4.1 & & 97.5 & 15 & M.salvarium.PG20 \\
\hline & 4.0 & 4.5 & 3.3 & 3.3 & 3.3 & 3.3 & 3.4 & 3.3 & 3.7 & 3.6 & 3.4 & 3.3 & 3.7 & 4.2 & 2.5 & & 16 & M.hyosynoviae.S-16 \\
\hline & 1 & 2 & 3 & 4 & 5 & 6 & 7 & 8 & 9 & 10 & 11 & 12 & 13 & 14 & 15 & 16 & & \\
\hline
\end{tabular}




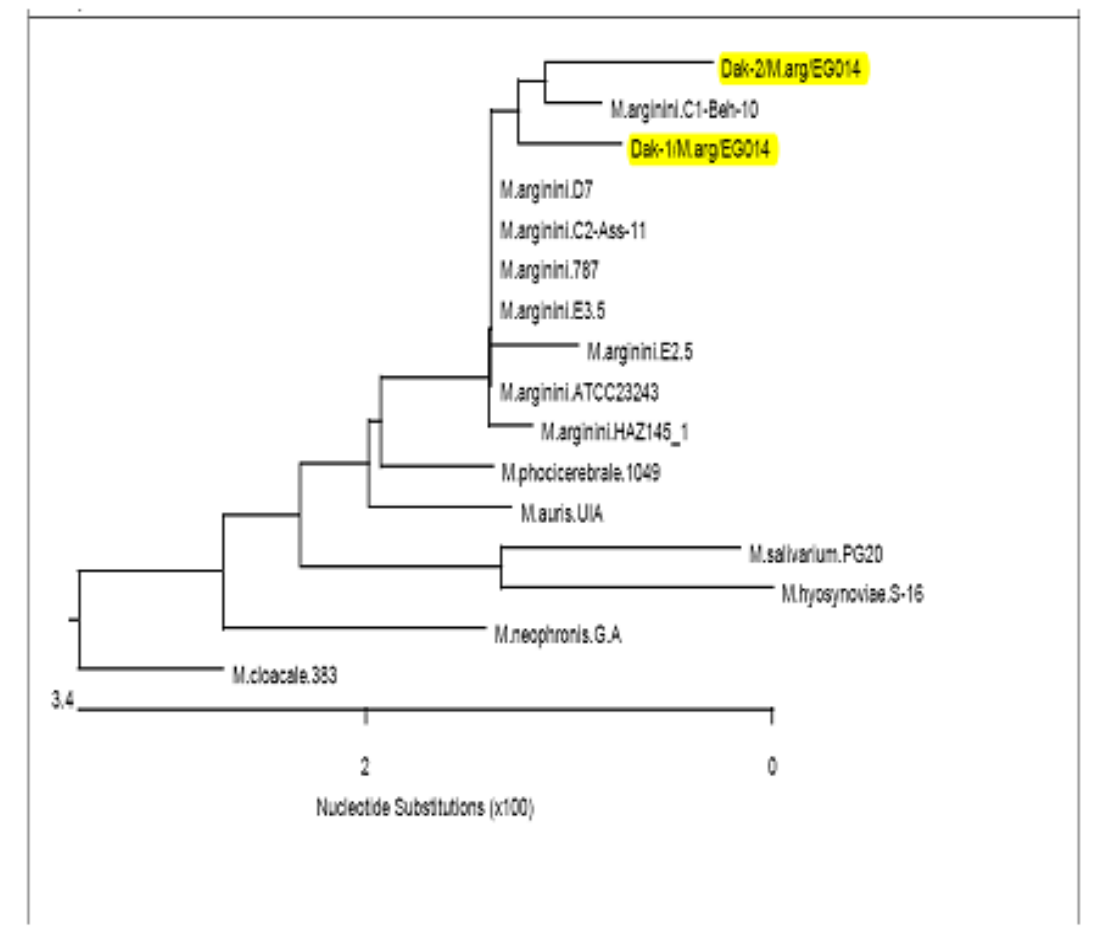

Fig. (5): Phylogenetic tree of Mycoplasma arginini 16s rRNA gene from sheep and goat with other Mycoplasma that were taken from the Gene Bank database 16s rRNA gene.

\section{DISCUSSION}

The respiratory diseases represent $5.6 \%$ of all diseases in small ruminants Hindson and Winter (2002) Small ruminants are especially sensitive to respiratory infections, namely, viruses, bacteria, and fungi, mostly as a result of deficient management practices that make these animals more susceptible to infectious agents. The tendency of these animals to huddle and group rearing practices additional predispose small ruminants to infectious and contagious diseases Kumar et al. (2014), in the examined flocks, by clinical examination, the percent of respiratory manifestation was $11.1 \%$ as 79 were positive from examined 712 sheep while in goat was $26.56 \%$ (81 from 305) examined goats, clinical manifestation varies from nasal discharge, cough to dyspnea. Table (2) and fig $(1,2)$.

Sheep and goats appear to be close to each other in the Mycoplasma flora, which affect them with rare exceptions; this can be clearly explained by the close phylogenetic relationship of these two animal species. In small ruminants Mycoplasma infections are common although it more frequently in goats than sheep. Some of these Mycoplasmas induce severe and contagious diseases with massive economic influence. From the most important $M$. spp for the ruminants are the $M$. mycoides cluster Cottew et al. (1987). Pneumonia in sheep has been associated with M. ovipneumoniae, M. capricolum subsp. capricolum, $M$. mycoides subsp. mcoides LC and M. arginini (Chaturvedi et al., 1992) and (Ikheloa et al., 2004).
M. arginini appears to be the second most common species isolated and it is often present in mixed culture with $M$. ovipneumoniae. M. arginini is less fastidious than $M$. ovipneumoniae and has the typical "fried-egg like" colony morphology unlike M.ovipneumoniae which lacks this phenomena (Goltz et al., 1986). In this study, M. arginini is closely associated with sheep and goat pneumonia. One of the most characteristic features of Mycoplasmas is inability to grow easily in laboratory media in spite of the great improvement in medium formulation so their isolation appeared to be too hard for diagnostic laboratories (Waleed et al., 2006), although isolation and identification of Mycoplasma still an efficient Toole in the diagnosis of Mycoplasma diseases. Multiple Mycoplasmas may well co-exist in goat lungs and, in that case, only the strains which grow well will be recovered. Sheep are less susceptible to pulmonary mycoplasmoses than goats (Thiaucourt and Bölske 1996), which is different with our results as the percentage of Mycoplasma isolation was nearly equal in sheep and goat but none of the isolates could be identified as one of the Mycoplasma mycoides cluster using PCR. Isolates were positive using $16 \mathrm{~S}$ rRNA gene primer used for ruminant Mycoplasma species detection giving a clear band at $1000 \mathrm{bp}$.

In spite of $M$. arginini is of less importance in pneumonia of sheep and goats; it is frequently isolated from their respiratory tract. This result is agreed with that mentioned by (Zaitoun, 2001) who was able to isolate $M$. arginini and $M$. agalactiae from cases of bronchopneumonia in sheep due to 
Mycoplasma alone or coupled with bacterial agents. In this study a total of 160 nasal swab were collected from sheep and goat suffer from respiratory manifestation for trails of Mycoplasma isolation and identification, our result in Table (3) \& Fig (3) revealed that, Mycoplasma spp. was isolated in 40 (25\%) nasal swab samples from 160 nasal swabs obtained from sheep and goats with respiratory manifestations. In sheep, percent of isolation was (25.32\%) (20 isolate from 79 nasal swabs) while the percent in goat was $(24.69 \%)$ (20 isolate from examined 81 nasal swabs), the obtained result were different from the result obtained by (Ammar et al., 2008), who isolated $M$. arginini from sheep and goats by $21.11 \%$ and $35.29 \%$ respectively from examined (131 samples from sheep and 41 samples from goats) obtained from animals from different areas in Sharkia governorate and El-Basatin abattoir in Cairo, the type of samples and its number may explain the difference between this study and result of our study.

In regarding to age our result observed, higher percent of isolation were found in age group (1-2) year old sheep (50\%) as 7 isolates from examined 14 nasal swab, while in goat were detected higher percent of isolation in age group less than one year old by $44 \%$ (11 isolates from examined 25 nasal swab). The lower isolation rates were observed in adult sheep and goats 3 - 4 year old by $15.38 \%$ in sheep and $6.45 \%$ in goat, which may clarify that, adult sheep and goat are less susceptible to infection with $M$. arginini.

In this investigation, $M$. spp, $M$. arginini, were identified from nasal swabs of sheep and goat rising in some farms at Dakahlia governorate Egypt, by PCR technique and nucleotide sequences of the $M$. arginini 16s rRNA. Others mentioned that Polymerase chain reaction more sensitive and specific technique that allows direct detection of antigen and overcomes to cross-reactions of conventional tests. A comparison of the PCR technique with the microbiological culture, DNA fluorochrome staining, and hybridization techniques indicated that the PCR is a rapid, sensitive, and efficient method (Ball and Finlay, 1998, Van Kuppeveld et al., 1994 and Gupta et al., 2015).

\section{CONCLUSIONS}

Mycoplasma arginni may play a role as a cause of respiratory manifestations in sheep and goat but further studies are needed for studying epidemiology of mycoplasma spp. Mycoplasma infection in sheep and goats must be considered during dealing with respiratory infection. Genome sequencing for immediate identification of Mollicutes species beside the ability to perform accurate analysis of multiple samples in a relatively short period compared to the current routinely used protocols existing a great improvement for a Mollicutes identification scheme. Mycoplasma arginini isolates designated in gene bank Dak-1/M.arg/EG014 and Dak-2/M.arg/EG014 for samples sequences KP972458 and KP972459 respectively.

\section{REFERENCES}

Alberto, A.; Addis, M.F.; Chessa, B.; Cubaddu, T.; Profiti, M.; Rosati, S.; Ruiu, A. and Pitau, M. (2006): Molecular and antigenic characterization of a Mycoplasma bovis strain causing an outbreak of infectious keratoconjunctivitis. J. Vet. Diagn. Invest. 18: 41-51.

Ammar, A.M.; Eissa, S.I.; Marwa, I. Abd El-Hamid; Hanaa, A .Ahmed and Abd ElAziz, E. (2008): Advanced Study on Mycoplasmas Isolated From Sheep and Goats. Zag. Vet. J.; 36(2): 128-137.

Ayşe Kılıc; Hakan Kalender; Hatice Eroksuz; Adile Muz and Bülent Tasdemir (2013): Identification by culture, PCR, and mmunohistochemistry of Mycoplasmas and their molecular typing in sheep and lamb lungs with pneumonia in Eastern Turkey .Trop Animal Health Prod ; 45(7): 15251531.

Ball, H.J. and Finlay, D. (1998): Diagnostic application of monoclonal antibody (MAb)based sandwich ELISAs. Methods Mol. Biol., 104, 127-132.

Chaturvedi, V.K.; Pathak, R.C. and Singh, P.P. (1992): Pathogenicity of Mycoplasma mycoides subsp. mycoides LC for sheep and lambs. Ind. J. Comp. Microbiol. Immunol. Infect. Dis., 13, 1-4.

Cottew, GS. (1979): Caprine-ovine Mycoplasmas. In: The Mycoplasmas. II. Human and animal Mycoplasmas, ed. Tully JG, Whitcomb RF, pp. 103-132. Academic Press, San Francisco, CA

Cottew, GS.; Breard, A.; Da Massa, AJ.; Ernф, H.; Leach, RH., Lefevre, PC., Rodwell, AW. and Smith, GR. (1987): Taxonomy of the Mycoplasma mycoides cluster. Israel Journal of Medical Sciences , 23(6): 632-635.

Erno, H. and Stipkovits, L. (1973): Bovine Mycoplasma: Cultural and biochemical studies. Act. Vet. Scan., 14: 450 - 463.11.

Fabricant, J. and Freundt, EA. (1967): Importance of extension and standardization of laboratory tests for the identification and classification of Mycoplasma. Ann N Y Acad Sci. Jul 28; 143(1): 50-8.

Goltz, J.P.; Rosendal, S.; Mccraw, B.M. and Ruhnke, H.L. (1986): Experimental Studies on the pathogenicity of Mycoplasma ovipneumoniae and Mycoplasma arginini for the respiratory tract of goats. Can. J. Vet. Res., 50, 59-67. 
Gupta S.; Chahota, R.; Bhardwaj, B.; Malik, P.; Verma, S. and sharma, M. (2015): Identification of chlamydiae and Mycoplasma species in ruminants with ocular infections. Letters in Applied Microbiology, Volume 60, February Issue 2, pages 135-139.

Hall, A. (1999): BioEdit: a user-friendly biological sequence alignment editor and analysis program for Windows 95/98/NT. Nuc. Acids Symp. Ser.41: 95-98.

Hindson J.C. and Winter, A.C. (2002): "Respiratory disease," in Manual of Sheep Diseases, pp. 196-209, Blackwell Science, Oxford, UK, 2nd edition.

Ikheloa, J.O.; Ajuwape, A.T.P. and Adetosoye, A.I. (2004): Biochemical characterization and serological identification of Mycoplasmas, isolated from pneumonic lungs of goats slaughtered in abattoirs in Northern Nigeria. Small Rumin. Res., 52, 93-97.

Kelly, W.R. (1990): Veterinary clinical diagnosis, 3rd Edition Bailliere Tidall, London.

Kumar, A.; Rahal A.; Chakraborty, S.; Verma A. K. and Dhama, K. (2014): "Mycoplasma agalactiae, an etiological agent of contagious agalactia in small ruminants-a Review," Veterinary Medicine International In Press, 2014.

Leach, RH. (1970): The occurrence of Mycoplasma arginini in several animal hosts. Vet Rec 87: 319-320.

Lin, Y.C.; Miles, R.J.; Nicholas, R.A.J.; Kelly, D.P. and Wood, A.P. (2008): Isolation and immunological detection of Mycoplasma ovipneumoniae in sheep with atypical pneumonia, and lack of a role for Mycoplasma arginini. Res. Vet. Sci., 84, 367-373.

Nicholas, R.; Ayling, R. and McAuliffe, L. (2008b): Respiratory diseases of small ruminants. In: Nicholas, R., Ayling, R., Mcauliffe, L., Eds. Mycoplasma Diseases of Ruminants. CABI, Wallingford, UK; 2008: 171-179

Nicholas, R.A.J.; Ayling, R.D. and Loria, G.R. (2008a): Ovine Mycoplasma infections. Small. Ruminant Res., 2008; 76: 92-98.

Ruragirwa, F.R. and McGuire, T.C. (2003): Contagious caprine pleuropneumonia: Diagnosis and control. Available online at http://file://A:/Contagious\#caprine\#pleuropn eumonia\#Diagnosis. and\#control.htm, p. 8

Sabry, M.Z. and Ahmed, A.A. (1975): Evaluation of culture procedure for primary isolation of Mycoplasmas from female genitalia of farm animals. J. Egypt. Vet. Med. Ass., 35: 18 34.9

Thiaucourt, F. and Bölske, G. (1996): Contagious caprine pleuropneumonia and other pulmonary mycoplasmoses of sheep and goats. Rev Sci ech. Dec; 15(4):1397-414.
Thomas E. Besser; Margaret A. Highland; Katherine Baker; E. Frances Cassirer; Neil J. Anderson; Jennifer M. Ramsey; Kristin Mansfi Eld; Darren L. Bruning; Peregrine Wolff; Joshua B. Smith and Jonathan A. Jenks (2012): Causes of Pneumonia Epizootics among Bighorn Sheep, Western United States, 2008-2010. Emerging Infectious Diseases www.cdc.gov/eid • Vol. 18, No. 3, March 406-414.

Thompson, D.; Higgins, G. and Gibson, J. (1994): CLUSTAL $\mathrm{W}$ : improving the sensitivity of progressive multiple sequence alignment through sequence weighting, positionspecific gap penalties and weight matrix choice. Nuc. Acids Res. 22: 4673-4680.

Thonney, M.L.; Smith, M.C.; Mateescu R.G. and Hеuеr, C. (2008): Vaccination of ewes and lambs against parainfluenza3 to prevent lamb pneumonia. Small. Ruminant Res., 2008; 74: 30-36.

Vankuppeveld, F.J.M.; Johansson, K.E.; Galama, J.M.D.; Kissing, J.; Bolske, G.; Vanderlogt, J.T.M. and Melchers, W.J.G. (1994): Detection of Mycoplasma contamination in cell cultures by a Mycoplasma GroupSpecific PCR. Appl. Environ. Microbiol., 60, 149-152.

Vijay Kumar; Rajneesh Rana; Somya Mehra and Pramod Kumar (2013): Isolation and Characterization of Mycoplasma mycoides Subspecies capri from Milk of Natural Goat Mastitis Cases. Veterinary Science, Article ID 593029, 1-5 pages.

Waleed Al-Momani; Mahmoud A. Halablab; Mahmoud N. Abo-Shehada; Katie Miles; Laura McAuliffe and Robin A.J. Nicholas (2006): Isolation and molecular identification of small ruminant Mycoplasmas in Jordan. Volume 65, Issues 1-2, September 2006, Pages 106-112.

Yechouron, A.; Lefebvre, J.; Robson, HG.; Rose, DL. and Tully, JG. (1992): Fatal septicemia due to Mycoplasma arginini: a new human zoonosis. Clin Infect Dis. Sep; 15(3): 434-8.

Yleana, R.C.J.; Bascunana, C.R.; Bolski, K.G.; Mattsson, J.G.; Molina, C.F. and Johansson, K.E. (1995): In vitro amplification of the 16S rRNA genes from $M$. bovis and $M$. agalactiae. Vet. Microbiol., 47: 183 - 190.

Zaitoun, A.M. (2001): Clinical study of pneumonic Mycoplasmosis and pasteurellosis (concurrent infection) in a commercial sheep flock. Assiut Vet. Med. J., 45 (89): 162-180.

Zendulkova, D.; Madanat, A.; Lany, P.; Rosenbergov, K. and Pospi, A.Z. (2007): Detection of Mycoplasma agalactiae by Polymerase Chain Reaction in Jordanian Sheep and Goat Herds. ACTA VET. BRNO, 76: 71-77; doi: 10.2754/avb200776010071. 


\section{عزل وتسلسل جينوم الميكوبلازما أرجينيني المرتبط بالاضطراب التنفسي في المجترات الصغيرة \\ دينا الشافعي ، نبرمين عوض ، باسر الناقر ، عماد بيونس}

E-mail: yasserelnaker@yahoo.com_ Assiut University web-site: www.aun.edu.eg

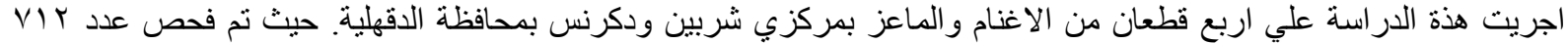

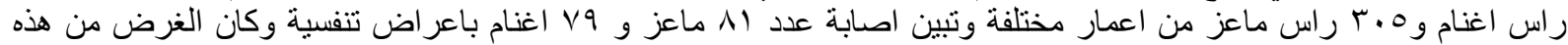

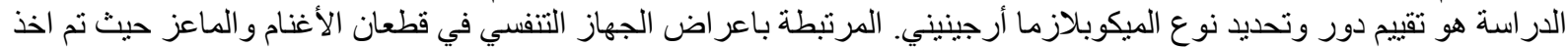

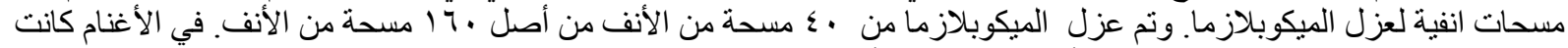

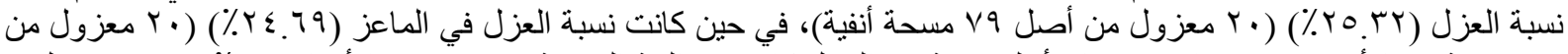

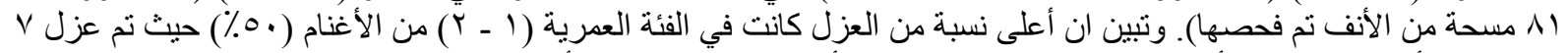

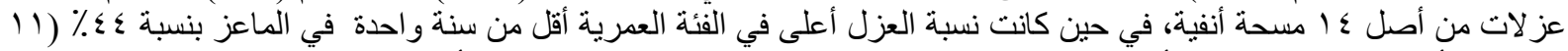

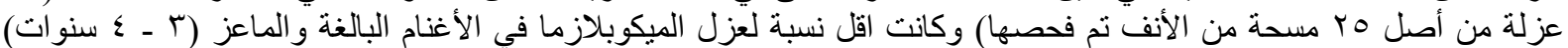

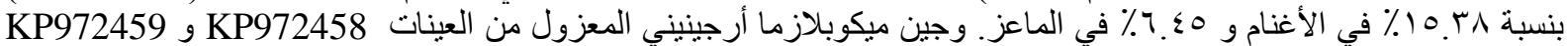

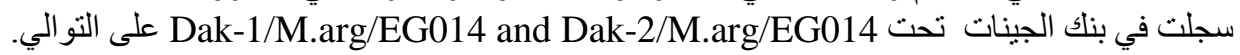

